
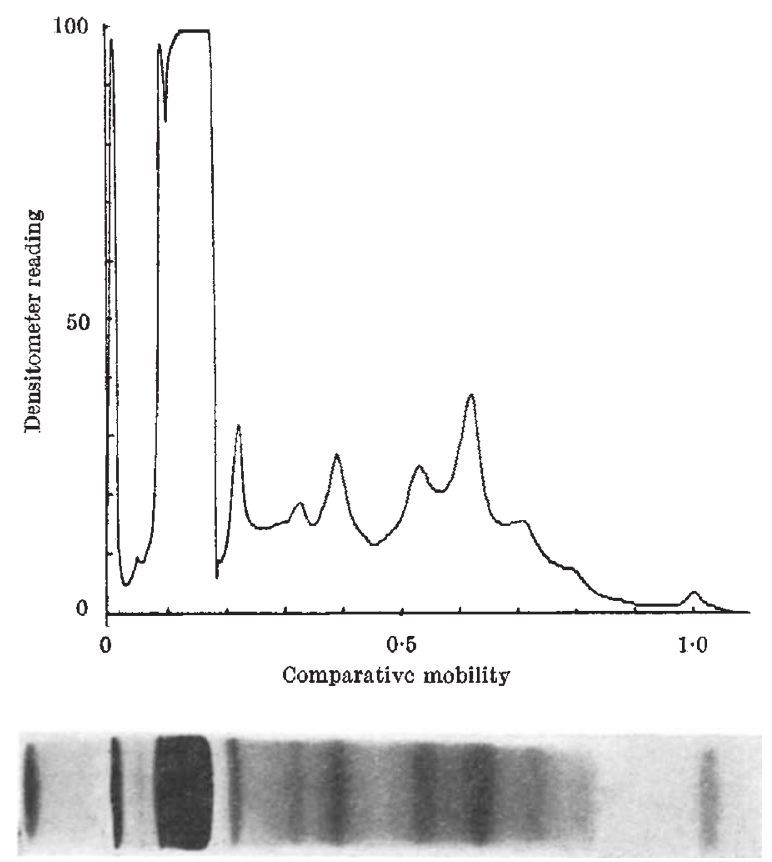

Fig. 1, Electrophoretic separation and corresponding densitometer migration is left to right. The large pore spacer gel protrudes to the lef of the origin

portod $^{7}$ to have a higher mobility than the other leaf proteins, its relatively large size (molecular weight of 375,000 (ref. 8)) was probably responsible for its low mobility in 7.5 per cent polyacrylamide (pore size 50 $\AA$ (ref, 6)).

At present fifteen to eighteen bands can bo distinguished and this may be improved by current investigations designed to refine the technique. The method is being used to investigate the role of loaf protoins in rust infection of whoat plants.

One of us (C. W. W.) wishes to acknowledge the award of a Commonwealth Research Studentship.

C. W. WRIGLEX

H. L. WEBSTER

Department of Agricultural Chemistry, J. F. TURNER

University of Sydney, Sydney. 'Heitefuss, R., Buchanan-Davidson, D. J., and Stahmann, M. A., Arch.
Biochem. Biophys., 85, 200 (1959).

"Mendiola, L., and Akazawa, T., Biochemistry, 3, 174 (1964).

a Staples, R. C., and Stahmann, M. A., Phytopathology, 54, 760 (1964).

' Racusen, D., and Calvanico, N., Anal. Biochem., 7, 62 (1964).

'Steward, F. C., and Barber, J. T., Ann. N.Y. Acad. Sci., 121, 525 (1904),

"Ornstein, L., and Davis, B. J., Disc Electrophoresis, preprinted by Distilla-

"Wildman, S. G., and Bonner, J., Arch. Biochem., 14, 381 (1947).

"Eggman, L., Singer, S. J., and Wildman, S. G., J. Biol. Chem., 205, 960 (1953).

\section{Available Lysine Content of Dried Milk}

THe heat treatment to which milk is subjected during drying causos some combination botween the $\varepsilon$-amino groups of lysine and lactose, which renders such lysine unavailable for nutritional purposes. Since drying conditions on rollors are more severe than in a spray chamber it is possible that there is less available lysine in roller-dried than in spray-dried powder. A series of available lysine determinations was made on both typos of powder from a number of factories to discover the extent of the loss of this essential amino-acid and to learn whether such losses are sufficient to cause any deficiency under normal conditions of feeding.

Four different batches of powder from separate factories were tested in duplicate, using Carpenter's ${ }^{1}$ dinitro- fluorobenzene method as modified by Rao et al. ${ }^{8}$, and correcting for the loss due to the acid hydrolysis in the presence of lactose. The results are shown in Table 1, together with figures for raw bulk milk. By comparing the results for liquid and dried milk an estimate can be made of the average percentage of lysine destroyed during production in each case.

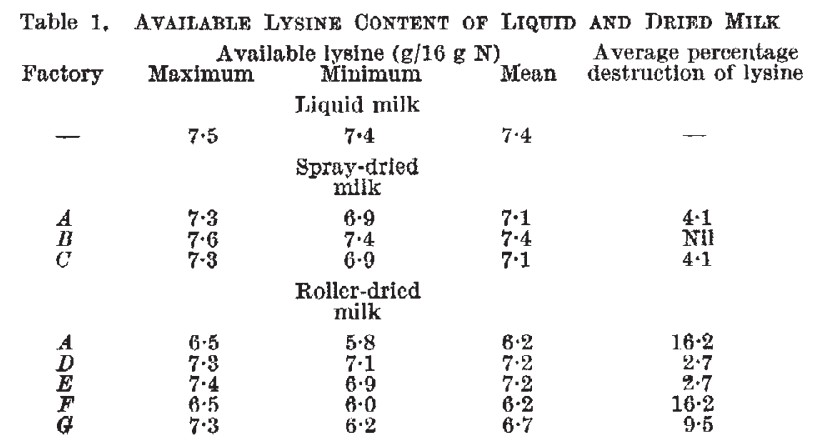

Table 2. COMParison OF THE AVAILABLE LYSINE OF HUMAN MTLK AND OF RECONSTITUTED FULL-CREAM ROLLER-DRIED POWDERS

\begin{tabular}{|c|c|c|c|}
\hline & $\begin{array}{c}\text { Available } \\
\text { lysine } \\
(\mathrm{g} / 16 \mathrm{~g} N)\end{array}$ & $\underset{\text { (per cent) }}{\text { Protein }}$ & $\begin{array}{c}\text { Avallable } \\
\text { lysine } \\
\text { (mg/100 ml.) }\end{array}$ \\
\hline Human milk (ref. 8) & $6 \cdot 2$ & 1.5 & 93 \\
\hline $\begin{array}{l}\text { Reconstituted full-cream roller powder, } \\
\text { best individual sample }\end{array}$ & $7 \cdot 4$ & $3 \cdot 3$ & 244 \\
\hline $\begin{array}{l}\text { Reconstituted full-cream roller powder, } \\
\text { worst individual sample }\end{array}$ & 5.8 & $3 \cdot 3$ & 191 \\
\hline
\end{tabular}

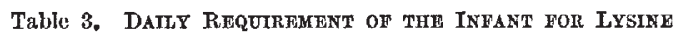
Minimum weight of lysine required per $\mathrm{kg}$ body-weight per day (ref. 4)
Weight of lysine supplied per kg body-weight per day by fullWeight of lysine supplied per
cream roller powder $(70 \mathrm{~g})$ :

(a) Best individual sample $103 \mathrm{mg}$ (b) Worst individual sample

The loss of lysine in the spray powders, and in the roller powders from factories $D$ and $E$, is very small. The loss is greater in roller powders from factories $A, F$ and $G$, but is in no caso sufficiently high to make these products deficient in this amino-acid when used for infant feeding. This aspect is demonstrated in Tables 2 and 3 , where comparisons are made with human milk and with the daily requirements of the infant.

All the individual samples of powder examinod are richer sources of lysine than is average human milk, and when fed in the proportions normally recommended for infants they will provide two and a half to three times the minimum daily roquirements.

F. J. Maddonald

Cow and Gate, Ltd.,

Guildford, Surrey.

${ }^{1}$ Carpenter, K. J., Ellinger, G. M., Munro, J. I., and Rolf, E. J., Brit. J.

${ }^{2}$ Rao, S. R., Carter, F. L., and Frampton, V. L., Anal. Chem., 35, 1927 (1963), ${ }^{3}$ United States National Research Council Bulletin 254, The Composition of Milks (1953).

${ }^{4}$ Holt, jun., L. E., and Snyderman, S. E., In Protein and A mino-Acid Requirements in Early Life, by Holt, jun., L. E., et al. (New York University Press, 1960).

\section{Production of Peptide Alkaloids in Submerged Culture by a Strain of Claviceps purpurea (Fr.) Tul.}

'l'He production of lysergic acid $\alpha$-othoxy amide in submerged culture by a strain of Claviceps paspali Stev. et Hall was reported earlicr ${ }^{1-3}$. The present communication describes the production of ergotamine in submerged culture by a strain of Claviceps purpurea (Fr.) Tul. isolated from a sclerotium found in Spain on a variety of 'Triticale (an artificial hybrid between wheat and rye). This strain (IC/39/20 of the collection of the Department of Biochemistry, Imperial Collogo of Science and T'echnology, London), unlike other strains of Claviceps purpurea, does not produce conidia in any of the media tested. The 